\title{
MENGANALISIS PERAN RUANG TERRBUKA HIJAU TERHADAP KONDISI LINGKUNGAN KOTA AMBON
}

\section{ANALYZE THE ROLE OF GREEN OPENED SPACE ON ENVIRONMENTAL CONDITIONS OF AMBON CITY}

\author{
Ngurmasa Refialy ${ }^{1)}$, Robert Oszaer $^{2}$, , Yosevita Latupapua ${ }^{3)}$, \\ Program Studi Manajemen Hutan, Program Pascasarjana, Universitas Pattimura \\ Penulis Korespondensi email : ngrefialy@gmail.com \\ \begin{tabular}{|l|l}
\hline Diterima: 20 Februari 2019 & Disetujui: 12 Maret 2019
\end{tabular}
}

\begin{abstract}
Abstrak
Penelitian ini bertujuan untuk menganalisis peran Ruang Terbuka Hijau Terhadap Pelestarian Lingkungan Kota Ambon. Metode pengumpulan data dilakukan dengan Pengumpulan data primer berupa pengukuran iklim mikro (suhu dan kelembaban udara) pada setiap lokasi RTH. Data iklim mikro kemudian diolah menggunakan microsof office excel, untuk mendapatakan hasil tabulasi dan grafik perbandingan. Setelah didapatkan nilai tabulasi data dilakukan analisis secara statistik dengan uji korelasi. teknik ini bertujuan untuk mengetahui pengaruh RTH terhadap suhu udara dan RTH terhadap kelembaban udara pada berbagai tipe ruang terbuka hijau. Untuk menganalisis pengaruh Ruang Terbuka Hijau terhadap pelestarian lingkungan kota Ambon dilakukan dengan alat statistic korelasi rank spearman dengan control Pearson. Hasil penelitian menunjukan Hasil pengukuran iklim mikro yang dilakukan pada Jalur Hijau jalan masing-masing Jalan Dr. Malaiholo, jalan Pattimura, jalan Piere Tandean, jalan Dr. Leimena, menunjukan suhu udara dan kelembaban rata-rata Jalan Dr. Malaihollo $32,3^{\circ} \mathrm{C}$ dan $\mathrm{RH} 68,5 \%$, jalan Pattimura $33,2^{\circ} \mathrm{C}$ dan RH $61,0 \%$, Jalan Piere Tandean $32,5^{\circ} \mathrm{C}$ dan $\mathrm{RH} 64,0 \%$, Jalan Dr. Leimena $33,0^{\circ} \mathrm{C}$ dan $\mathrm{RH} 56,7 \%$. Berdasarkan hasil Analisis Kenyamanan keempat Jalur hijau tersebut tergolong tidak nyaman karena rata-rata berada pada nilai $>27$.
\end{abstract}

Kata Kunci : RTH, Kota Ambon, Iklim mikro, Korelasi Spearman.

\begin{abstract}
This study aims to analyze the role of Green Open Space on Environmental Protection in Ambon City. The method of data collection is done by collecting primary data in the form of micro climate measurements (temperature and air humidity) at each RTH location. Micro climate data is then processed using microscope office excel, to get the results of comparison tabulations and graphs. After the data tabulation value was obtained statistically analyzed by correlation test. this technique aims to determine the effect of green space on air temperature and green space on air humidity in various types of green open spaces. To analyze the effect of Green Open Space on the preservation of the environment of the city of Ambon, a Spearman correlation correlation tool with Pearson control was performed. The results showed that the results of the microclimate measurements carried out on the Green Path each way Dr. Malaiholo, Pattimura road, Piere Tandean road, Dr. Leimena, shows the air temperature and average humidity of Dr. Malaihollo $32.3{ }^{\circ} \mathrm{C}$ and $\mathrm{RH} 68.5 \%$, Pattimura road $33.2{ }^{\circ} \mathrm{C}$ and $\mathrm{RH}$ $61.0 \%$, Jalan Piere Tandean $32.5^{\circ} \mathrm{C}$ and RH 64.0\%, Jalan Dr. Leimena $33.0{ }^{\circ} \mathrm{C}$ and RH 56.7\%. Based on the results of the Convenience Analysis, the four green lines are classified as uncomfortable because the average is in the value of $>27$.
\end{abstract}

Keywords: RTH, Ambon City, Micro Climate, Spearman Correlation. 


\section{PENDAHULUAN}

Ruang terbuka hijau atau yang sering disingkat RTH memiliki banyak pengertian. Didalam pengaturannya RTH juga dapat disebut dengan ruang terbuka hijau kawasan perkotaan (RTHKP). Fungsi hijau dalam ruang terbuka hijau (RTH) kota sebagai 'paru-paru' kota, merupakan salah satu aspek berlangsungnya fungsi daur ulang, antara gas karbondioksida $\left(\mathrm{CO}_{2}\right)$ dan oksigen (O2), hasil fotosintesis khususnya pada dedaunan (Arifianty, dkk 2014).

Ruang terbuka hijau kota merupakan pertemuan antara sistem alam dan manusia dalam lingkungan perkotaan (urban). Kawasan perkotaan yang berkelanjutan ditandai oleh interaksi dan hubungan timbal balik yang seimbang antara manusia dan alam yang hidup berdampingan di dalamnya. Pada kasus lingkungan perkotaan berkepadatan tinggi, keseimbangan tersebut mengalami gangguan akibat berkurangnya ruang terbuka hijau. Oleh karena itu, mengembalikannya ke dalam lingkungan perkotaan dengan berbentuk sistem dinilai penting (Rahmy, 2012).

Pentingnya keberadaan ruang terbuka hijau kota, terutama dalam lingkungan tempat tinggal, telah dibuktikan dalam beberapa penelitian (Wu, 2008). Ruang terbuka hijau kota merupakan komponen penting yang mempengaruhi kualitas kehidupan manusia, baik secara ekologis maupun sosial-psikologis. Namun demikian, saat ini proporsinya semakin berkurang sebagai dampak dari tingginya kepadatan penduduk akibat pertumbuhan populasi manusia yang semakin meningkat (Rahmy, 2012). .

Isu mengenai masalah lingkungan hidup semakin menjadi bahasan yang menarik dewasa ini. Salah satu permasalahan yang kini dihadapi oleh hampir seluruh perkotaan di Indonesia adalah semakin berkurangnya lingkungan dan ruang publik terutama Ruang Terbuka Hijau. Kota-kota pada umunya memiliki ruang terbuka hijau dengan luas dibawah $10 \%$ dari luas kota itu sendiri. Kondisi ini sangat jauh dibawah ketentuan pemerintah pada Undang-undang No. 26 Tahun 2007 tentang Ruang Terbuka Hijau yang mewajibkan pengelolaan perkotaan yang menyediakan Ruang Terbuka Hijau public dengan luas sekitar 20\% dari luas kota tersebut.

Kurangnya proporsi Ruang Terbuka Hijau di kawasan perkotan disebabkan oleh lebih tingginya permintaan lahan untuk kegiatan perkotaan. Sementara banyak pihak menganggap Ruang Terbuka Hijau memiliki nilai ekonomi yang lebih rendah sehingga termarjinalkan. Dengan berlakunya undang-undang tentang penataan ruang, banyak banyak pemerintah daerah yang merasa kesulitan dalam memenuhi ketentuan penyediaan RTH publik seluas 20\% dari luas kawasan perkotaan. Kekurangan proporsi Ruang 
Terbuka Hijau yang ada di kota-kota di Indonesia disebabkan oleh pembangunan yang tidak merata dan kian mempersempit Ruang Terbuka Hijau yang ada.

RTH diklasifikasikan berdasarkan status kawasan, bukan berdasarkna bentuk dan struktur vegetasinya,. Menurut Undangundang RI No. 26 Tahun 2017 tentang penataan ruang dinyatakan bahwa proporsi RTH pada wilayah perkotaan paling sedikit $30 \%$ dari luas wilayah keseluruhan. Di wilayah kota Ambon masih ditemui fakta bahwa dalam pembangunan infrastrukur, kawasan Ruang Terbuka Hijau (RTH) masih mengalami berbagai kelemahan dari segi tata ruang dan penataan kota serta realisasi kebijakan yang berlaku. Hal ini tentunya mangakibatkan perkembangan Ruang Terbuka Hijau (RTH) di Kota Ambon semakin mengalami distorsi (pembiasan) dalam hal peran dan fungsi sebagai paru-paru kota dari dampak pencemaran akibat polusi kendaraan dan kawasan insustri di pusat kota (Hatulesila, dkk. 2017).

Kota Ambon sebagai ibukota Propinsi Maluku juga sedang menghadapi proses pembangunan dengan segala permasalahannya, dalam beberapa tahun terakhir ini pembangunan pemukiman, perdagangan, pariwisata, pendidikan, dan sektor-sektor lainnya mengalami pertumbuhan yang relatif pesat dibandingkan dengan kawasan lain disekitarnya. Pembangunan tersebut di satu sisi membutuhkan ketersediaan sumberdaya alam seperti lahan dan air, sementara Kota Ambon yang terletak di pulau Ambon merupakan pulau yang relatif kecil dan memiliki ketersediaan sumberdaya lahan dan air yang terbatas baik dalam jumlah maupun sebarannya (Dahuri et al., 1996). Hal ini sering menimbulkan konflik dalam pemanfaatannya, yang berakhir dalam bentuk banyaknya perubahan (konversi) penggunaan lahan (Suhendy, 2009).

Terbatasnya ketersediaan lahan disatu sisi serta tuntutan kebutuhan pembangunan kawasan kota, disisi lain telah menyebabkan perubahan atau pergeseran terhadap penggunaan lahan yang ada, dan menunjukan indikasi terjadinya dampak negatif terhadap lingkungan. Jika pelaksanaan pembangunan di kawasan ini terus meningkat tanpa mempertimbangkan pengelolaan pengelolaan yang baik terhadap Ruang Terbuka Hijau (RTH) yang ada, maka dikawatirkan akan berdampak serius terhadap kelestarian lingkungan, yang pada akhirnya akan mempengaruhi keberlanjutan dari pembangunan itu sendiri.

\section{Tujuan Penelitian}

Adapun tujuanndari penelitian ini adalah untuk mengetahui peran ruang terrbuka hijau terhadap kondisi lingkungan kota ambon.

\section{METODE PENELITIAN}

Tempat dan Waktu 
Lokasi Penelitian ditetapkan di kota Ambon, dengan pertimbangan bahwa Kota Ambon yang menjadi ibu kota Provinsi Maluku memiliki taman-taman kota, jalur hijau, hutan kota, serta kota Ambon memiliki program kegiatan penghijauan yang telah terprogram dengan baik, dan taman-taman kota yang telah ditatah dengan baik oleh pihak Pemda Kota Ambon.

Penelitian ini dilaksanakan dari bulan Januari 2019 sampai Februari 2019, dimulai dari pembuatan peta penentuan titik lokasi penelitian, pengambilan data di lapangan, pengolahan data dan penyusunan thesis.

\section{Pengumpulan Data}

Pengumpulan data primer dilakukan setelah groundcheck dan pengurusan izin pengambilan data pada lokasi terpilih kemudian dilakukan pengukuran iklim mikro (suhu dan kelembaban udara) pada setiap lokasi Ruang Terbukan Hijau (RTH) yang telah ditentukan sedangkan pengumpulan data sekunder diperoleh dari instansi-instansi terkait.

\section{Lokasi dan Titik Pengambilan Data}

Titik pengambilan data yang dipilih pada kawasan RTH berbentuk jalur yang berada di tengah-tengah kawasan perkotaan (Jalan Dr. Malaihollo, Jalan Pattimura, Jalan Piere Tandean, Jalan Dr. Leimena). Pengukuran iklim mikro (suhu dan kelembaban udara) diukur dibawah naungan pohon yang tingginya $+-8 \mathrm{~m}$ dengan tajuk bulat dan berfungsi sebagai penaung.

\section{Metode Pengukuran Suhu dan Kelembaban Udara}

Pengambilan data pada penelitian ini dilihat dari peta lokasi pengambilan data. Setelah didapatkan lokasi pengambilan data, setiap kawasan kemudian ditentukan titik dimana alat pengukuran akan ditempatkan dengan pertimbangan pohon yang memiliki naungan dengan tingkat kerapatan yang tinggi.

Pengambilan data diambil selama 30 menit pada vegetasi pohon yang telah dipilih dengan rentang waktu pukul 12.00 13.00 WIT, dilakukan pada saat cuaca cerah. Waktu tersebut dipilih karena merupakan waktu ketika radiasi matahari paling terik dan suhu udara paling tinggi. Pengambilan data dilakukan selama 3 hari pada masing-masing titik sebagai ulangan karena yang dibandingkan adalah iklim mikro dengan vegetasi pada berbagai tipe ruang terbuka hijau (Jalur hijau dan Taman Kota).

\section{Pengolahan Data dan Analisis}

Data iklim mikro yang sudah diperoleh dari hasil pengukuran dilapangan dengan menggunakan alat ukur iklim mikro digital, diolah menggunakan microsof office excel, untuk mendapatakan hasil tabulasi dan grafik perbandingan, tujuannya adalah untuk membedakan kondisi iklim mikro 
pada setiap titik RTH baik Taman Kota maupun Jalur Hijau Jalan. Setelah didapatkan nilai tabulasi data dilakukan analisis secara statistik dengan uji korelasi. teknik ini bertujuan untuk mengetahui pengaruh RTH terhadap suhu udara dan RTH terhadap kelembaban udara pada berbagai tipe ruang terbuka hijau.

Berdasarkan hal tersebut didalam melakukan uji korelasi digunakan hipotesis statistic, yaitu :

Uji korelasi dilakukan untuk mengetahui apakah ada hubungan antara RTH dengan suhu udara dan kelembaban udara pada ruang terbuka hijau (Taman Kota dan Jalur Hijau). Uji korelasi dilakukan dengan mengggunakan Software SPSS dengan Analisis Pearson Correlasion. Kegunaan teknik ini ialah untuk menguji hipotesis yang membuktikan hubungan RTH dengan Iklim mikro (Sarwono, 2009). mengetahui tingkat kenyamanan yang dipakai oleh Nieuwolt sebagai berikut :

$$
\mathrm{THI}=0,8 \mathrm{~T}+\frac{(\mathrm{RH} \times \mathrm{T})}{500}
$$

Keterangan :

$$
\begin{array}{ll}
\mathrm{THI} & =\text { Themperature Humidity Index } \\
\mathrm{T} & =\text { Rata-rata Temperature Udara }
\end{array}
$$

$\mathrm{RH}=$ Rata-rata Kelembaban Udara (\%)

Themperature Humidity Index (THI) adalah indeks yang menunjukan tingkat kenyamanan suatu area secara kuantitatif berdasarkan nilai suhu dan kelembaban relative. Suhu daerah tropis kategori tidak nyaman nilai THI > 26 dan suatu area dikatakan nyaman apabila nilai THI berkisar 21-26.

Tabel 1. Kriteria Tingkat Kenyamanan Daerah Tropis

\begin{tabular}{cc}
\hline Kriteri & Nilai Index $\left({ }^{\circ} \mathrm{C}\right)$ \\
\hline Nyaman & $21-24$ \\
Sedang & $25-26$ \\
Tidak Nyaman & $>26$ \\
\hline
\end{tabular}

Sumber: Neuwolt and Mc Gregor (1998)

Analisis selanjutnya yang dilakukan adalah analisis kenyamanan iklim mikro pada setiap Lokasi RTH. Tingkat kenyamanan secara kuantitatif biasanya diperoleh dengan menggunakan angka Temperature Humidity Index (THI). Satu diantara rumus yang dipakai untuk
Untuk menganalisis pengaruh Ruang Terbuka Hijau terhadap pelestarian lingkungan di wilayah kota Ambon dilakukan dengan alat statistic korelasi rank spearman dengan control Pearson (Nasir, 1988). 


$$
r_{s}=1-\frac{6 \sum d_{i}^{2}}{n\left(n^{2}-1\right.}+\cdots
$$

Di mana $: f_{s}=$ Koefisien Korelasi Pearson

$$
\begin{aligned}
& d_{i}=\text { beda antara } 2 \text { pengamatan } \\
& \quad \text { berpasangan } \\
& n=\text { total sampel }
\end{aligned}
$$

untuk menguji signifikasi pada taraf $\propto=$ 0,05 digunakan rumus uji " $\mathrm{t}$ " dengan $d k=n$ - 2 (Siegel, 1944) dengan rumus :

$$
t-r_{s} \sqrt{\frac{n-2}{1-r_{s}^{2}}}
$$

\section{HASIL DAN PEMBAHASAN}

\section{Hasil Pengukuran Iklim Mikro}

\section{Iklim Mikro Kawasan RTH Taman Pattimura}

Luas ruang terbuka hijau di Ambon semakin lama semakin berkurang seiring dengan meningkatnya jumlah penduduk dan peningkatan kebutuhan lahan. Adanya batasan wilayah kota mendorong pembangunan cenderung memanfaatkan lahan-lahan alami yang masih ada, padahal lahan-lahan tersebut mempunyai fungsi ekologis kota. Berkurangnya ruang terbuka hijau dan bertambahnya dominasi lahan terbangun di Kota Ambon.

Taman kota, taman lingkungan dan taman rekreasi di Ambon pada umumnya berbentuk arean hijau dengan luasan tertentu karena banyak digunakan masyarakat untuk berbagai kegiatan sedangkan ruang terbuka hijau berada di tepi jalan, sepadan sungai dan tepian pantai berbentuk koridor jalur hijau (Green corridor). Ambon memiliki banyak taman kota, salah satu taman kota yang cukup besar di Ambon adalah Taman Pattimura (Pattimura Park) yang berada di pusat kota. Pengambilan data pada penelitian ini dilakukan di taman Pattimura selama 3 hari mulai tanggal 3 - 5 Februari 2019. Taman Pattimura didominasi vegetasi (Pohon, semak dan rumput) yang memiliki jarak tanam yang cukup rapat. Selain landsekap tanaman juga ada landscape lainya seperti lapangan olahraga, patung pattimura, kolam air dan bangunan. Pengukuran suhu udara dan kelembaban udara dilakukan pada siang hari saat cuaca cerah yaitu pada pukul 12.00-13.00 WIT. Suhu dan kelembaban udara diukur di bawah naungan pohon Trembesi (Zamanea saman) setinggi \pm 8 meter dengan kepadatan tajuk yang cukup rapat. Data suhu udara dan kelembaban udara yang didapatkan dari hasil pengukuran selama 30 menit dapat dilihat pada Gambar 8.

\section{A. Suhu Udara}

Suhu udara merupakan salah satu unsur iklim mikro yang mempengaruhi kenyamanan taman kota. Rata-rata ulangan hasil pengukuran suhu udara selama tiga hari tersebut menunjukan perbedaan setiap menit pengukuran. 


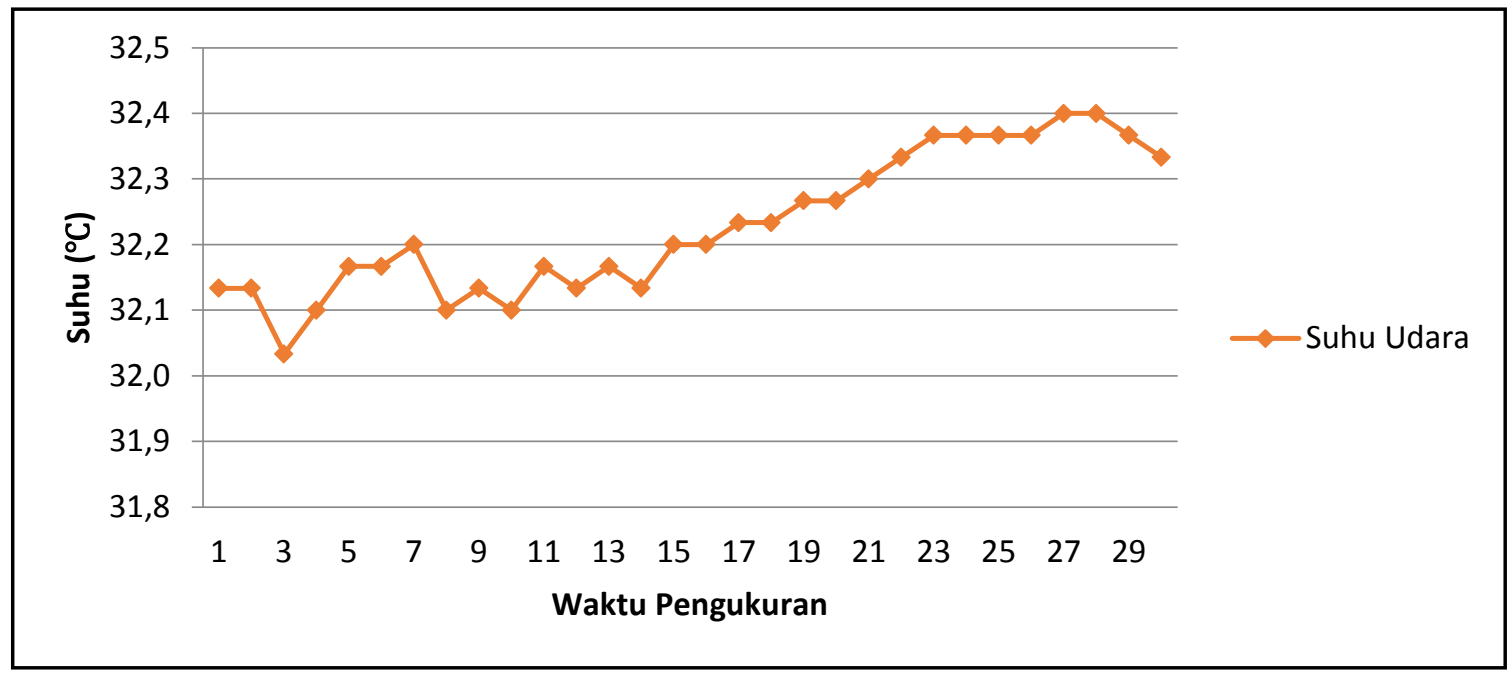

Gambar 1. Grafik Suhu Udara di Kawasan Taman Pattimura

Perbandingan laju perubahan suhu udara lebih jelas dapat dilihat pada grafik Gambar 8. Grafik di atas merupakan grafik rata-rata suhu udara pada struktur vegetasi pohon setiap menitnya pada Taman Pattimura. Pengukuran suhu pada vegetasi pohon di Taman Pattimura menunjukan bahwa keadaan suhu udara pada struktur vegetasi pohon tidak begitu mengalami perubahan tiap menitnya, tetapi sering mengalami perubahan pada waktu tertentu. Hal ini dikarenakan perubahan cuaca kota saat dilakukan pengukuran yaitu adanya tutupan awan yang mempengaruhi penyinaran matahari tetapi perubahan itu tidak cukup berarti karena saat berikutnya suhu kembali ke awal pengukuran. Ratarata suhu udara pada Taman Pattimura adalah $32,2^{\circ} \mathrm{C}$

Suhu udara sangat di pengaruhi oleh kerapatan pohon, semakin tinggi kerapatan maka suhu udara di bawah naungan dan area taman kota semakin rendah. Hal ini disebabkan tajuk pohon yang rapat saling bersinggungan sehingga menyebabkan radiasi matahari tidak langsung mampu menembus permukaan. Selain itu tajuk pohon dapat menyebarkan sinar matahari sehingga suhu area di sekitarnya dapat direduksi (Sari, 2013).

\section{Kelembaban Udara}

Kelembaban udara merupakan salah satu unsur iklim mikro yang mempengaruhi kenyamanan taman kota. Rata-rata ulangan hasil pengukuran kekembaban udara selama tiga hari tersebut menunjukan perbedaan setiap menit pengukuran.

Perbandingan laju perubahan kelembaban udara lebih jelas dapat dilihat pada grafik (Gambar 2). Gambar 2 merupakan grafik rata-rata kelembaban udara pada struktur vegetasi pohon setiap menitnya pada Taman Pattimura. Pengukuran kelembaban udara pada vegetasi pohon di Taman Pattimura 


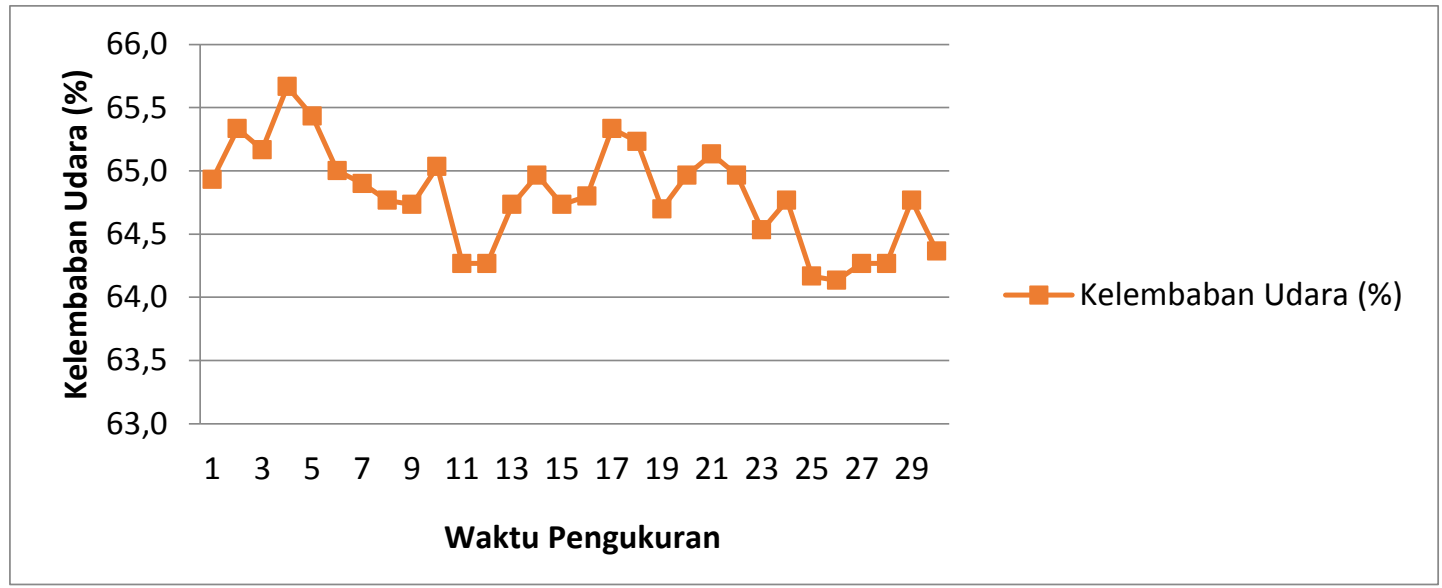

Gambar 2. Grafik Kelembaban Udara di Kawasan Taman Pattimura

menunjukan bahwa keadaan kelembaban udara pada struktur vegetasi pohon selalu mengalami perubahan tiap menitnya. Hal ini dikarenakan perubahan cuaca kota saat dilakukan pengukuran yaitu adanya tutupan awan yang mempengaruhi penyinaran matahari tetapi perubahan itu tidak cukup berarti karena saat berikutnya kelembaban Udara kembali ke awal pengukuran. Rata-rata kelembaban udara pada Taman Pattimura adalah $64,4 \%$.

\section{Iklim Mikro RTH Jalur Hijau Jalan}

Pengambilan data pada penelitian ini dilakukan di 4 jalur hijau jalan antara lain Jalan Dr. Malaiholo, Jalan Pattimura, Jalan Dr. Leimena, Jalan Piere Tandean selama 3 hari. Dan hubungan suhu udara dengan Kelembaban Udara dapat dilihat pada Gambar 3.

\section{Suhu Udara}

Suhu udara merupakan salah satu unsur iklim mikro yang mempengaruhi

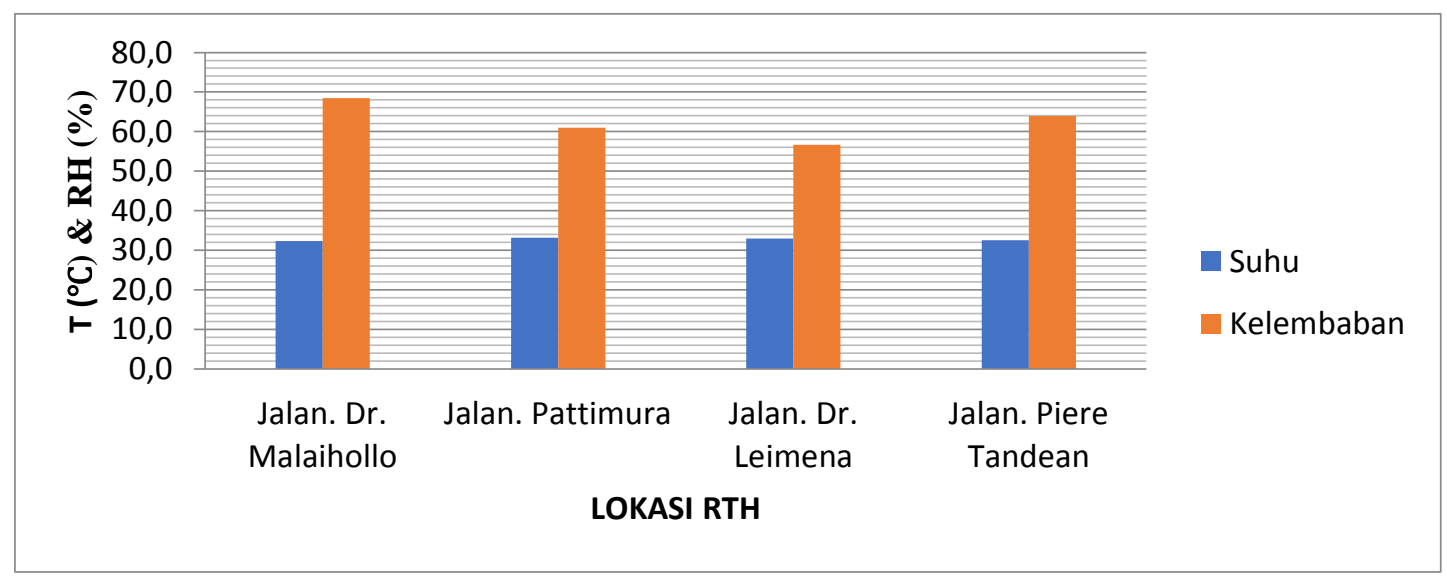

Gambar 3. Hubungan Suhu Udara dengan Kelembaban Udara Jalur Hijau Kota 
kenyamanan taman kota. Rata-rata ulangan hasil pengukuran suhu udara selama tiga hari pada Jalur Hijau (Jalan Dr. Malaiholo, Jalan Pattimura, Jalan Dr. Leimena, Jalan Piere Tandean) menunjukan perbedaan yang signifikan. Perbandingan perubahan suhu udara lebih jelas dapat dilihat pada grafik (Gambar 3).
Untuk mengetahui arah hubungannya bisa dilihat dari tanda koofisien korelasinya. Apabila tanda (-) berarti jika variable RTH tinggi maka variabel suhu udara rendah, sedangkan tanda $(+)$ berarti jika variable RTH tinggi maka variabel suhu udara juga ikut tinggi. Hal ini arah hubungannya semakin tinggi variabel RTH maka variabel

\begin{tabular}{llrr}
\hline \multicolumn{1}{c}{ Correlations } & & \multicolumn{1}{c}{ SUHU } \\
\multirow{2}{*}{ RTH } & RTH & \multicolumn{2}{c}{-.271} \\
& Pearson Correlation & & .729 \\
& Sig. (2-tailed) & 4 & 4 \\
\multirow{3}{*}{ SUHU } & N & -.271 & 1 \\
& Pearson Correlation & .729 & \\
& Sig. (2-tailed) & 4 & 4 \\
\hline
\end{tabular}

Gambar 4. Hubungan Suhu Udara dengan Kelembaban Udara Jalur Hijau Kota

Berdasarkan Tabel 5, diketahui bahwa besarnya Sig. (2-tailed) adalah 0,729. H0 diterima jika besar signifikansi > 0,05. Dan H0 ditolak jika besar signifikansi $<$ 0,05. Pada Gambar 4 diketahui bahwa besarnya signifikansi 0,729 lebih besar dari 0,05 dengan demikian Ho diterima yang berarti tidak ada pengaruh antar variable kondisi RTH dengan suhu udara di Jalur hijau Kota Ambon. Menurut interval kekuatan yang dibuat oleh (Sarwono, 2009). maka besar nilai korelasi RTH terhadap suhu udara di Kota Ambon sebesar -0,271, berarti RTH tidak memiliki pengaruh terhadap suhu udara di Kota Ambon.
Suhu Udara semakin rendah. RTH dengan kondisi baik ditunjukan dengan luas lahan dan banyaknya pepohonan yang tertata. Jalur hijau jalan pada empat titik pengamatan memiliki kerapatan yang berbeda-beda sehingga pengearuhnya terhadap suhu udara sekitar juga berbeda. Selain itu jenis tanaman ikut mempengaruhi suhu udara di Jalur Hijau Jalan. Jenis tanaman yang ada pada 4 titik Jalur hijau jalan merupakan tanaman perindang dan besar, jenis tanaman ini memiliki fungsi mampu menyerap $\mathrm{CO}_{2}$.

\section{Kelembaban Udara}

Pengukuran kelembaban udara Jalur hijau jalan pada setiap kondisi ruang 


\section{Correlations}

\begin{tabular}{llrr} 
& & RTH & KELEMBABAN \\
RTH & Pearson Correlation & 1 & .618 \\
& Sig. (2-tailed) & & .382 \\
& N & 4 & 4 \\
KELEMBABAN & Pearson Correlation & .618 & 1 \\
& Sig. (2-tailed) & .382 & \\
& $\mathrm{~N}$ & 4 & 4 \\
\hline
\end{tabular}

Gambar 5. Hubungan Suhu Udara dengan Kelembaban Udara Jalur Hijau Kota

terbuka hijau di kota Ambon diwakili 4 titik lokasi pengamatan. Antar lain Jalur

Hijau Jalan Dr. Malaiholo, Jalan Pattimura, Jalan Dr. Leimena, Jalan Piere Tandean.

Penelitian ini menggunakan analisis korelasi dengan menggunakan SPSS 25. Hasil analisis korelasi hubungan antara RTH dengan suhu udara dapat dilihat pada Gambar 5. Berdasarkan nilai rata-rata pengukuran kelembaban udara untuk empat titik pengamatan terlihat bahwa ada perbedaan yang signifikan, hal ini terjadi karena struktur vegetasi keempat jalur hijau jalan berbeda antara jenis pohon penedu, jumlah pohon dan kerapatan.

Berdasarkan analisi korelasi diketahui bahwa besarnya Sig. (2-tailed) adalah 0,618. H0 diterima jika besar signifikansi > 0,05. Dan H0 ditolak jika besar signifikansi $<0,05$. Pada Tabel 5.4 diketahui bahwa besarnya signifikansi 0,382 lebih besar dari 0,05 dengan demikian H0 diterima yang berarti ada pengaruh antar variable kondisi RTH dengan kelembaban udara di Jalur hijau Kota Ambon. Menurut derajat hubungan

yang dibuat oleh (Sarwono, 2019), maka besar nilai pearson korelasi RTH terhadap suhu udara di Kota Ambon sebesar 0,618 termasuk berkorelasi kuat, berarti RTH memiliki pengaruh terhadap kelembaban udara di Kota Ambon dengan nilai pearson korelasi kuat.

Untuk mengetahui arah hubungannya bisa dilihat dari tanda koofisien korelasinya. Apabila tanda (-) berarti jika variable RTH tinggi maka variebl suhu udara rendah, sedangkan tanda $(+)$ berarti jika variable RTH tinggi maka variabel suhu udara juga ikut tinggi. Gambar 5 diketahui bahwa besarnya koefisien korelasinya yaitu sebesar 0,618. dengan ini arah hubungannya semakin tinggi variabel RTH maka variabel Kelembaban Udara semakin rendah.

Tingginya kelembaban udara sangat dipengaruhi oleh vegetasi penyusunnya, vegetasi pohon memiliki kemampuan 
menghasilkan uap air melalui proses evapotranspirasi (Edi, 2013). Dari hasil pengukuran menunjukan tajuk pohon pada Taman Pattimura yang memiliki kerapatan yang cukup tinggi, hal ini menyebabkan uap air yang dihasilkan dari evapotraspirasi oleh vegetasi juga tinggi.

\section{Tingkat Kenyamanan}

Kenyamanan lingkungan rata-rata Ruang Terbuka Hijau Taman Kota dan Jalur Hijau di Kota Ambon tergolong tidak nyaman. Nilai THI tersebut diperoleh dari suhu udara rata-rata dan kelembaban udara rata-rata di lokasi pengukuran (Tabel 2).
Nilai THI rata-rata pada Taman Pattimura 29,96, jalur hijau jalan pada jalan Dr. Malaiholo 30,29, Jalan Pattimura 30,59, Jalan Dr. Leimena 30,10 dan Jalan Piere Tandean 30,20 Menurut teteapan Neuwolt kondisi ini termasuk dalam kategori tidak nyaman.

Tabel 2. Tabel Tingkat Kenyamana RTH Kota Ambon berdasarkan THI

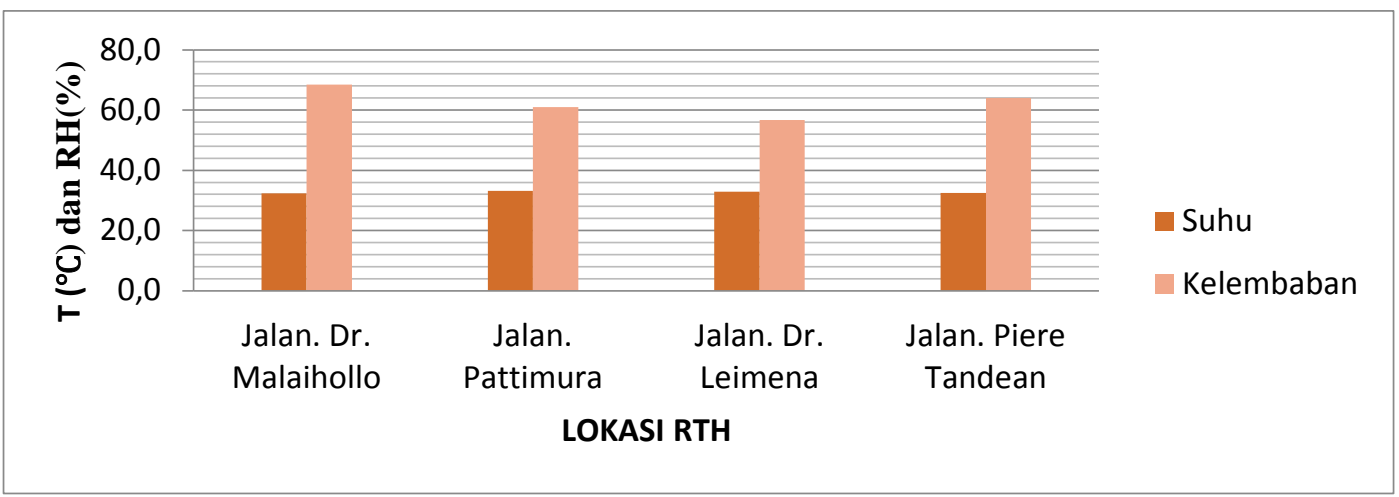

\begin{tabular}{|c|c|c|c|c|}
\hline \multirow[t]{2}{*}{ Lokasi } & \multicolumn{2}{|c|}{ Faktor } & \multirow[t]{2}{*}{ THI } & \multirow[t]{2}{*}{ Kriteria } \\
\hline & Suhu $\left({ }^{\circ} \mathrm{C}\right)$ & RH (\%) & & \\
\hline Pattimura Park & 32,2 & 64,8 & 29,96 & Tidak Nyaman \\
\hline J1. Dr. Malaihollo & 32,3 & 68,5 & 30,29 & Tidak Nyaman \\
\hline Jl. Pattimura & 33,2 & 61,0 & 30,59 & Tidak Nyaman \\
\hline Jl. Dr. Leimena & 33,0 & 56,7 & 30,10 & Tidak Nyaman \\
\hline Jl. Piere Tandean & 32,5 & 64,0 & 30,20 & Tidak Nyaman \\
\hline
\end{tabular}

Gambar 6. Diagram rata-rata Suhu Udara dan Kelembaban Udara RTH Kota Ambon. 
suhu nyaman manusia tropis adalah $24-28^{\circ} \mathrm{C}$ dengan kelembaban 40-60\%. Taman kota Pattimura dan tersusun atas pohon yang heterogen sehingga kemampuan masing-masing pohon dalam menyerap radiasi matahari dan mereduksi suhu udara berbeda-beda. Pada Taman Pattimura masih didominasi oleh vegetasi dan memiliki tajuk cukup rapat sehingga memberikan efek naungan yang cukup baik namun suhu udara belum tereduksi secara maksimal. Sedangkan pada jalur hijau jalan jumlah pohon dan tajuk yang sangat jarang dan kurang ternaungi sehingga sinar matahari tidak terhalang tajuk pohon untuk sampai ke permukaan tanah.

\section{KESIMPULAN DAN SARAN}

\section{Kesimpulan}

Berdasarkan tujuan dan hasil penelitian maka dapat di ambil beberapa kesimpulan antara lain :

1. Hasil pengukuran iklim mikro yang dilakukan pada ruang terbuka hijau Taman Kota Pattimura Park, terdapat perbedaan suhu udara dan kelembaban udara pada pengukuran setiap menitnya selama 30 menit, hasil pengukuran suhu udara rata-ratanya $32,2^{\circ} \mathrm{C}$, kelembaban udara rata-rata $64,4^{\circ} \mathrm{C}$. Berdasarkan hasil analisis tingkat kenyamanan Taman Pattimura tergolong tidak nyaman karena ratarata berada pada nilai $>27$.
2. Berdasarkan hasil Analisis Kenyamanan keempat Jalur hijau tersebut tergolong tidak nyaman karena rata-rata berada pada nilai $>27$. Pada jalur hijau jalan memiliki kerapatan vegetasi yang jarang hingga sangat jarang. sehingga direkomendasikan suatu penataan lansekap yang baik, menanam vegetasi pohon penyerap pencemar yang banyak untuk mendapatkan udara kawasan yang sehat.

\section{Saran}

Kenyamanan masyarakat pengguna RTH di Kota Ambon dalam hal ini suhu dan kelembaban udara yang baik dapat dipenuhi dengan dilakukannya penanaman pada jalur hijau jalan yang belum terisi vegetasi dengan pemilihan jenis spesies pohon yang memiliki potensi penyerapan $\mathrm{CO}_{2}$ yang tinggi serta lebih mengintensifkan pemeliharaan vegetasi tegakan pohon yang telah ada sehingga dapat menyerap karbon dioksida secara maksimal.

\section{DAFTAR PUSTAKA}

Arifiyanti.H. N., Awaluddin M., Sabri L. M., 2014. Analisis Ruang Terbuka Hijau Kota Semarang Dengan Meggunakan Sistem Informasi Geografis. Jurnal.Volume 3, Nomor 1, Tahun 2014, (ISSN : 2337845X).Geodesi Undip Januari 2014.

Edi, S. 2013. Pengaruh Struktur Vegetasi Terhadap Iklim Mikro Kawasan Kota 
Tanggerang. Skripsi. Institut Pertanian Bogor. Bogor. 69 p.

Hatulesila, J.W.,Mardiatmoko. G., dan Wattimury.J., 2017.Analisis Spasial Ruang Terbuka Hijau (RTH) untuk Penanganan Perubahan Iklim di Kota Ambon, Jurnal. Fakultas Pertanian dan Fakultas Perikanan dan Ilmu Kelautan. Universitas Pattimura.

Nasir, M., 1988. Metode Penelitian, Penerbit Ghalia Indonesia, Jakarta.

Rahmy. W. A., Faisal. B., Soeriatmadjo. A. R., 2012. Kebutuhan Ruang Terbuka Hijau Kota pada Kawasan Padat, Studi Kasus di Wilayah Tegallega, Bandung. Jurnal Lingkungan Binaan Indonesia Vol.1 No.1 Juli 2012 | 27.

Sari, N. A. 2013. Evaluasi Hutan Kota Berdasarkan Fungsi Ameliorasi Iklim Mikro di Kota Semarang. Skripsi. Institut Pertanian Bogor. Bogor. 40 p.

Sarwono, J. (2009) Prosedur-Prosedur Populer Statistik untuk mempermudah Riset.

Suhendy, C.C.V., 2009. Kajian Spasial Kebutuhan Hutan Kota Berbasis Hidrologi Di Kota Ambon. Tesis, Sekolah Pascasarjana Institut Pertanian Bogor, Bogor. 